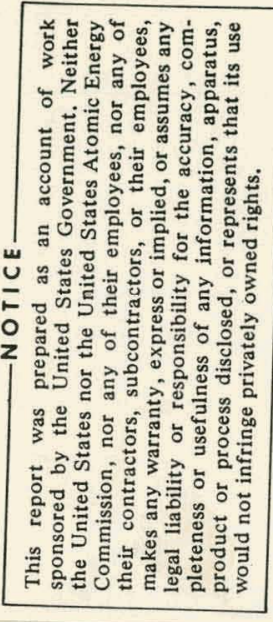

\title{
Radioactive Wastes from Nuclear Power in the U.S.A.
}

\section{MASTER}

\author{
By \\ K. J. Schneider, Batelle, Pacific Northwest Laboratories
}

This paper was prepared for the Environmental Quality Conference for the Extractive Industries of the American Institute of Mining, Metallurgical, and Petroleum Engineers, Inc., to be held in Washington, D. C., June 7-9, 1971. Permission to copy is restricted to an abstract of not more than 300 words. Illustrations may not be copied. The abstract should contain conspicuous acknowledgment of where and by whom the paper is presented.

\section{ABSTRACT}

The generation of electricity from nuclear power in the U.S.A. is expected to increase by a factor of approximately 10 to about 150,000 MW in 1980, and continue to increase to about $1,000,000 \mathrm{MW}$ in the year 2000 . The associated radioactive wastes which are generated will tend to grow approximately proportional to the growth of nuclear power. To date, the fastgrowing nuclear industry has been one of the most carefully controlled and successful industries in minimizing detrimental impact on our environment by waste effluents.

An overview of the radioactive waste situation from the mainline nuclear power activities is presented. The overall waste problems from the basic fuel cycle, from mining of the fuel materials, through electrical generation in the nuclear reactor, to reprocessing and recycle of fuel, are discussed, and emission values are estimated for 1970. The most significant source of wastes is during the reprocessing of the spent nuclear fuel, where more than $99 \%$ of the significant radioactive byproduct constituents are separaled into waste streams. References and illustrations at end of paper.
In general, radionuclide content in gaseous and liquid effluents are held to small fractions of 1 imits set by the Environmental Protection Agency and the International Committee on Radiation Protection. Most contaminants in gaseous wastes are reduced to low levels in effluents by processing or by holdup to permit decay of radionuclides or by dilution with large volumes of air before the gas stream is discharged to the atmosphere. Liquid wastes are generally treated to remove radionuclides before process recycle of the treated liquid or before its discharge. Residues from 1 iquid waste treatment are generally converted to solids and buried in established state or federal repositories, as are other solid wastes.

\section{INTRODUCTION}

Nuclear power is one of the fastest growing industries in the USA. Commercial nuclear power has grown from the startup of the first nuclear power reactor, the Shippingport reactor, in 1957 to approximately 10,000 MW today, and is expected to grow to about $150,000 \mathrm{MW}$ in 1980 , and to about 1,000,000 MW in the year 2000. The industry is unique in that its development 


\section{DISCLAIMER}

This report was prepared as an account of work sponsored by an agency of the United States Government. Neither the United States Government nor any agency Thereof, nor any of their employees, makes any warranty, express or implied, or assumes any legal liability or responsibility for the accuracy, completeness, or usefulness of any information, apparatus, product, or process disclosed, or represents that its use would not infringe privately owned rights. Reference herein to any specific commercial product, process, or service by trade name, trademark, manufacturer, or otherwise does not necessarily constitute or imply its endorsement, recommendation, or favoring by the United States Government or any agency thereof. The views and opinions of authors expressed herein do not necessarily state or reflect those of the United States Government or any agency thereof. 


\section{DISCLAIMER}

Portions of this document may be illegible in electronic image products. Images are produced from the best available original document. 
from the outset was based upon the overriding concern for the public health and safety. Development of this technical industry has been paralleled by development of safety knowledge and procedures for the hazards involved with the toxic radionuclides associated with it.

Conservative regulations of radionuclide emissions were established at the beginning by the former Federal Radiation Councila, using bases established by the International Commission on Radiation Protection (ICRP) and the United States' National Committee on Radiation Protection and Measurements. These regulations have generally been based on factors of conservatism applied to knowledqe of biological effects which were determined from broadbased biological research programs. In addition, it has become policy of the regulatory agencies to restrict further emissions to those that are "as low as practicable." This statement is generally

interpreted to mean performance which can reasonably be achieved should be done, even though the regulations can easily be met without the added degree of safety.

To date, most phases of the relatively young nuclear power industry have generally kept their radionuclide emissions to a few percent of these conservative regulations. Even with such unusually good performance, the nuclear power industry has come under the public spotlight to approach "zero release," particularly in view of the projected rapid growth of the industry. It is obviously impractical to achieve true "zero release" in any industry, so that some smal1 amount of releases will always occur.

The projected growth of nuclear power is shown in Figure 1. (i) The shaded area shows the range of projections, and the solid line shows the current best estimate of growth. By any standards, the future growth rate is very rapid.

\section{BACKGROUND ON RADIOACTIVE WASTES}

Decay of rndinactive atulls from their excited states occurs at rates specific to each radionuclide, and these rates vary from half-lives of fractions of seconds to billions of years. The radionuclides which are the most important from the standpoint of waste emissions decay to half their previous radioactivity over periods of days to tens of years. $b, c$ The more important

a. The standards are now established by the Environmental Protection Agency.

b. Radioactivity is expressed in curies; 1 curie is $3.7 \times 1010$ radioactive trarisformations per second. radionuclides in the wastes are listed in Table 1. The maximum permissible concentrations (MPC)d, the half-lives, and the phase of the nuclear power industry wherein each radionuclide is more important is also shown in the table. Relative importance of radionuclides in wastes depends upon the toxicity and the relative amourt of the nuclide present.

The toxicity of radionuclides is caused by the destruction of matter upon bombardment by the nuclear particles or photons. On a comparable weight basis, the most toxic radionuclides are more toxic than the most poisonous chemicals by a factor of about one million. The toxic effects of radionuclides cannot be "neutralized" by chemical reaction or by any currently-practicable scheme. The only way to "neutralize" a radionuclide is to let it decay to very low levels at its own specific decay rate.

Two methods are generally used to treat radioactive wastes: concentrate and confine, and dilute and disperse. In the former, the wastes are concentrated to a reasonably small volume and are stored in a fashion which will 1 imit the release of the radionuclides while they decay. In the latter technique, the concentration is diluted by water or air to acceptable values. Both techniques are used to advantage in most facilities, but the trend is more toward concentration and confinement, for obvious reasons.

Radionuclides may be present in gaseous, liquid, or solid form. Solid wastes per se are not important as potential contaminants of man's biosphere until they are converted to the gaseous form (usually as airborne particulates) or to the liquid form by leaching. Consequently, environmental effects and regulatory limits are based only on liquid and gaseous forms (even though solids may be present in either fluid phase).

Radioactive wastes are usually categorized as low- to high-level wastes, depending on the concentration of radionuclides. One scheme which may be used and which contains tive cateyuries is shown in lable 2. The oversimplified table is based upon the assumption that the waste contains only the most toxic radionuclides. The second lowlevel category is based upon maximum permissible concentrations (MPC) as specified by the ICRP. In this country, these values are allowed only for persons employed in a c. To convert between curies and grams, curies $=\frac{1.3 \times 10^{8}}{\text { At. Wt } \times \text { Half-Life(in days) }} \times$ grams . d. MPC's are for occupational exposure in accordance with 10CFR20(2) 
nuclear-related industry. Limits for the population at large are generally about $1 / 30$ of the MPC values as shown in the first category. The intermediate level wastes are treated (or sometimes diluted) to reduce concentrations to acceptable levels. Wastes in the last two categories always require treatment or storage, and the high-level wastes have sufficiently high concentrations of radionuclides to cause significant selfheating of the waste by radioactive decay. The wastes encountered in the pre-reactor portion of the nuclear fuel cycle (i.e., mining, milling, purification, and enrichment of uranium, and fuel element fabrication) are generally in the low and intermediate categories. Some of the wastes generated in the nuclear reactors and the fuel reprocessing steps can be in any category, but include high-level wastes. These wastes usually require heavy shielding to reduce the dose rate to personnel to acceptablc levels.

\section{THE FUEL CYCLE}

The mainline activities in the nuclear power industry are those directly associated with the "fuel cycle," shown in simplified form in Figure 2. The fuel cycle includes all major nuclear activities required to generate electricity and to recycle fuel materials into the cycle. For simplicity, the nuclear fuel cycle in this report consists of the following steps:

1. Uranium mining and milling;

2. Uranium purification and conversion to uranium hexafluoride;

3. Uranium enrichment;

4. Uranium and plutonium conversion to oxide and fabrication into fuel elements ;

5. Nuclear fission in nuclear reactors;

6. Reprocessing of spent fuel from reactors.

Because the intense or high levels of radioactivity are formed in the reactor, steps 5 and 6 are the only steps wherein high-level wastcs can be found. Furthermore, because almost all of the intensely radioactive constituents are contained within the fuel element package within the reactor, and because these fuel elements are then "destroyed" in the reprocessing step, most of these highly radioactive nuclides become available as wastes in the last step. The first four steps usually involve only low or intermediate level wastes.

The radioactive wastes in each step in the fuel cycle dre discussed in the following sections, with summaries of major emissions for 1970 .

\section{Uranium Mining and Milling}

Domestic uranium ores are mined from several hundred mines and transported to approximately 20 mills for initial purification. In the mills the ore is usually crushed and ground, leached with acid or alkali, purified by one or more combinations of solvent extraction, ion exchange, or precipitation, then precipitated and dried for shipment as moderately pure yellow cake ( $\mathrm{U}_{3} \mathrm{O}_{8}$ or diuranate salt).

The primary "waste" problem in uranium mining is emission of gaseous, radioactive radon-222 which is formed by natural decay of the radium-226 present in uranium ores. Radon-222, in turn, decays rapidly to several nongaseous radionuclide "daughters" which have relatively high toxicity. When radon-222-containing air is breathed, the particulate radionuclide daughters tend to be absorbed in the lungs. In addition to gaseous radioradon and its decay products, the mine air contains dust which contains uranium, radium, and other radjoactive constituents, but the quantities of these present a less severe problem than that of radon-222.

The radon-222 and its decay products are discharged with the mine air to the atmosphere where they are rapidly diluted to insignificant concentrations. The primary health problem of concern is in the mine itself where concentrations of the radionuclides can exceed values which are safe for long-term exposure if proper precautiulls are not taken. The main control techniques are to supply adequate ventilation air to all parts of the mines which are occupied by personnel, seal off unused sections of mines, and to filter or clean the air. In some cases, respirators are worn by the mine occupants.

Over the past 25 years the average radon-222 concentration in domestic mines has been reduced from about 15 working levels to about $?$ working level (WL). (a,3) This reduction has been accomplished by mine design, by improved natural ventilation, and by forced circulation of clean air to all inhabited parts of the mine to maintain 3 to 20 air changes per hour. Some particulate removal is also done by fogs and filtration.

a. A working level (WL) is a concentration of radon-222 of $1 \times 10^{-7} \mu \mathrm{Ci} / \mathrm{Cc}$ in the air, or about $3 \times 10^{-7} \mu \mathrm{Ci} / \mathrm{CC}$ including the decay of the radioactlve daughters. The total yearly exposure to workers is presently limited to no more than 12 WLM (working level months). 
Essentially no liquid or solid wastes are generated during the mining operation. However, liquid, solid, and gaseous wastes are evolved during the milling of the ores and conversion of the recovered uranium to moderately pure yellow cake.

The major radioactivity in wastes discharged from 1970 milling operations is estimated in Table 3.(4) As in the mining operation, the primary airborne radionuclide is radon-222, although radon is generally present in smaller concentrations in milling than in mining. The amount of the other, nongaseous radionuclides which are airborne as particulates, is not known. However, the amounts of these particulates are sufficiently low that they present less of a health hazard than the nonradioactive dust. Consequently, the controls used to minimize siliceous dust in the air (proper ventilation and air cleaning) provide good protection from exposure to airborne radlonuclides.

Radium-226 is the most hazardous radionuclide which is present in the solid waste from the mills. This waste, which includes all the gangue, the slimes, and some process liquors, is impounded in tailing ponds. Some of the water in these "solid" wastes is evaporated in the ponds, some of it is recycled to the process after most solids settle out, and a small, unknown amount percolates into the ground from the ponds.

In recent years, milling operations have incorporated more and more recycle and reuse of process liquors to minimize the amounts discharged to the environment. The amounts discharged to the "environment" (other than those with the solids) are shown as liquid discharges in Table 3 . The radionuclide present in liquid wastes in the amounts of the most biological significance is thorium-230. Most of the volume of liquid discharge is to surface rivers and lakes. However, most of the radionuclides are discharged underground by deep well injection.

\section{Uranium Purification and Conversion to Uranium Hexafluoride}

The yellow cake from the milling plants is shipped to plants which provide final purification of the uranium to the quality suitable for use in reactors, then is converted to uranium hexafluoride $\left(U_{6}\right)$ for later enrichment of the uranium-235 content. The purification and conversion to $\mathrm{UF}_{6}$ involves calcination to uranium trioxide $\left(\mathrm{UO}_{3}\right)$, hydrogen reduction and hydrofluorination to uranium tetrafluoride $\left(\mathrm{UF}_{4}\right)$, fluorination to $\mathrm{UF}_{6}$, and fractional distillation of the
$\mathrm{UF}_{6}{ }^{\mathrm{a}}$ or solvent extraction of the original yellow cake. This processing is done in either of two commercial plants.

Process waste treatment includes primary scrubbing of the gases and vapors to recover chemicals and uranium, packaging the ash from fluorination, and chemically treating and recycling the bottoms from fractional distillation.

The total waste discharges for 1970 from the two plants are estimated in Table 4. (4) Many of the discharge numbers are not available, but these are all at concentrations less than MPC, and the radionuclide content is generally much less than those shown in the table.

Essentially no gaseous radon exists in purification and conversion, because it was released in the previous milling step and thousands of years would be required for significant amounts to "grow-in" again.

At both sites the aqueous solution used to scrub hydrogen fluoride from the process ventilation gases is discharged to rivers after recovery of most chemical and product values. The raffinate from solvent extraction from the one plant, and the aqueous waste from chemical recovery of product values from the fractional distillation wastes from the other plant are impounded into ponds for evaporation of the water and settling of solids. The solid waste, which consists primarily of contaminated inert fluidized bed material and ash from the fluorination steps, is put into barrels and stored.

\section{Uranium Enrichment}

Most natural uranium for domestic power reactors is enriched before use in the reactors. The enrichment of uranium-235 from $0.72 \%$ of the total uranium in the ore to 2 to $4 \%$ is done by gaseous diffusion of $\mathrm{UF}_{6}$ in two AEC plants as a service to the commercial industry. (A third AEC plant is used primarily to enrich uranium to higher enrichment levels for other purposes.)

In the enrichment step, the uranium is separated into an enriched uranium product stream, and a discard stream which is depleted in uranium to 0.2 to $0.3 \%$ uranium- 235 . The depleted uranium is stored on-site in metal cylinders as $U_{6} 6$ for possible future use as fertile material in reactors for specific uses.

a. $\mathrm{UF}_{6}$ vaporizes at $56^{\circ} \mathrm{C}$ at 1 atmosphere pressure. 
By the time the uranium reaches the enrichment stage, essentially all other radionuclides have been removed. Consequently, the only radioactive element of any significance in the associated wastes is uranium. The total waste discharges from enrichment of uranium for power reactor fuels in 1970 were:

\section{$0.09 \mathrm{Ci}$ of uranium to atmosphere ${ }^{\mathrm{a}}$ \\ $0.7 \mathrm{Ci}$ of uranium to riversa.}

No solid wastes are discharged from the enrichment step. The airborne wastes are those which leak from process equipment and those which pass the bag filters and cold traps which treat the process vents. The liquid waste which discharges into rivers is overflow from holding ponds where settling of chemical wastes is accomplished. These solutions are wastes from chemical recovery of uranium from incineration of combustible wastes, from flushes of process equipment, and from off-gas treatment.

Uranium and Plutonium Conversion to 0xide and Fabrication into Fuel Elements

Uranium is normally received at the fuel fabrication plants from the enrichment step as UF 6 , and plutonium is normally received from the fuel reprocessing step as an aqueous solution of $\mathrm{Pu}\left(\mathrm{NO}_{3}\right)_{4}$. Conversion of these materials to their chemical forms for nuclear fuel elements, $\mathrm{UO}_{2}$ and $\mathrm{PuO}_{2}$, is normally done at the fuel fabrication plant. Uranium hexafluoride is usually converted to $\mathrm{UO}_{2}$ by aqueous chemical precipitation to ammonium diurinate [ADU, $\left.\left(\mathrm{NH}_{4}\right)_{2} \mathrm{U}_{2} \mathrm{O}_{7}\right]$ followed by calcination and reduction to the fuel form. Plutonium nitrate is converted to $\mathrm{PuO}_{2}$ by aqueous chemical precipitation to plutonium oxalate $\left[\mathrm{Pu}\left(\mathrm{C}_{2} \mathrm{O}_{4}\right)_{2}\right]$ and/or by calcination to $\mathrm{PuO}_{2}$.

The $\mathrm{UO}_{2}$ and $\mathrm{PuO}_{2}$ are then ground, granulated, classified to the correct particle sizes, and pressed into pellets which are then sintered to form an acceptable fuel material. These pellets are then ground and loaded into tubes of fuel cladding material (usually a zirconium alloy). The remaining hardware is fitted into the open end of the tube and the tube is sealed by welding. The tube is then mounted into a framework with 40 to 230 additional tubes to form a fuel assembly, ready for use in a nuclear reactor.

a. Approximately half is U-238 and half is $\mathrm{U}-234$, with small amounts of U-235 and U-236. Total uranium is approximately $130 \mathrm{~kg}$ to the atmosphere and approximately $1000 \mathrm{~kg}$ to rivers.
Waste effluents from the fuel fabrication industry in 1970, are estimated in Tables $5 a$ and $5 b .(6,7)$ Gaseous wastes consist of airborne particulates of fuel materials which are removed by filters. The material collected on the filters is removed chemically and returned to the process. The exact values in Table $5 b$ for plutonium in airborne emissions are not defined but they are known to be very small, due to the use of high-efficiency filters.

Liquid wastes from uranium are primarily process filtrates which contain sma 11 amounts of fuel materials and laboratory solutions. These filtrates are treated by precipitation for removal of radionuclides before discharge of the cleaned supernates. Liquid plutonium-containing wastes are mixed with concrete or are adsorbed onto solids such as fuller's earth or diatomaceous earth, and packaged into containers for land burial. Actual plutonium emissions from the plants as liquids are not well defined, but are extremely low.

Solid wastes consist of the above liquid wastes which were converted to solids, miscellaneous contaminated equipment, and contaminated materials used for cleanup such as rags, paper, etc. These solid wastes which contain plutonium are currently packed in mechanically-sealed steel drums and shipped to one of four authorized sites for land burial. Uraniumcontaining solid wastes are placed in steel drums or wood or cardboard containers, and are usually buried on the site of the fuel fabricators.

\section{Nuclear Fission in the Nuclear Reactor}

The newly fabricated and tested fuel assemblies are inserted into a nuclear reactor. Here bombardment by neutrons of the radionuclides $\mathrm{U}-235, \mathrm{Pu}-239$, and $\mathrm{Pu}-241$ causes these nuclides to fission into two smaller atomic nuclei with the emission of additional neutrons and energy. These neutrons, in turn, bombard additional fissile nuclides and continue the chain reaction. The two smaller atomic nuclei are fission products, most of which are radioactive. These fission or waste products are highly concentrated in the fuel materials, and thus form the source of high-level radioactivity. (However, essentially all of the radioactive fission products [except some short-1ived gaseous radionuclides] are retained in the fut elements until the fuels are shipped to the reprocessing plant.) The energy is 
relloved by a coolant, usually boiling or pressurized water, which is used to generate electricity through a turbine, then is recycled to the nuclear reactor.

Radioactive gaseous wastes from nuclear reactors are comprised primarily of gaseous activation products and noble gas fission products. The fission products leak or diffuse through the fuel el ement cladding and go into the water coolant from which they are vented. Although a large number of curies of these gases are emitted, the majority of these radionuclides are unreactive chemically and have relatively short half-lives, so that they decay rapidly to nontoxic levels. Radionuclides which are discharged in the greatest quantities are shown in Table 6. (8) These gases al so contain hydrogen and oxygen from radiolytic decomposition of the cooling water. Treatment consists of condensation of condensable vapors, holdup for 30 minutes to days to permit decay of radionuclides, then release to the atmosphere through highefficiency filters.

Radioactive liquid wastes from nuclear reactors result primarily from coolant system leakage, contaminated laundry drains, equipment decontamination solutions, spent solutions from regenerating ion exchange systems, shielding water for refueling and for fuel storate pools, and chemical analysis and miscellaneous activities. The radionuclides present in the greatest quantities in liquid reactor effluents are shown in Table 6 . The radionuclides in the coolant system are generated by activation of materials in the water coolant or in the reactor materials, and by some diffusion of radionuclides through the fuel element cladding. Treatment of the liquid wastes consists primarily of ion exchange, filtration, and/or evaporation to result in cleaned solutions which are reused, if possible, or are discharged to surface waters. The filter sludge and evaporator bottoms are then processed as "solid" wastes (see below). The liquid discharges $(200,000$ to about $6,000,000 \mathrm{gal} / . \mathrm{yr})$ are conmonly diluted with the large volumes $(500,000$ to $5,000,000 \mathrm{gal} . / \mathrm{min})$ of condenser cooling water from a $1000 \mathrm{MW}$ reactor before discharge to the river.

Solid radioactive wastes from nuclear reactors result primarily from spent ion exchange resins, filter sludges and cartridges, waste concentrator bottoms, and miscellaneous failed equipment and decontamination equipment. These materials are generally centrifuged and/or dried or compacted and packaged into 30 to 55 gallon drums, sometimes with concrete shielding. stored temporarily on-site, then shipped to an authorized radioactive waste repository for burial. The principal radionuclides in these wastes are shown in Table 6 . Shown separately are the radioactive activation products ${ }^{a}$ discharged in used equipment and control rods.

Overall control of radionuclide emission from nuclear reactors has been very good. In general, emission have ranged from a maximum of a few percent of permissible amounts down to less than 0.001 percent.

\section{Reprocessing of Spent Fuel from Reactors}

The spent fuel, which contains essentially all of the intensely radioactive elements, is discharged from the nuclear reactor and stored in water for approximately six months to allow the relatively shortlived radionuclides to decay. The spent fuel is then shipped to the reprocessing plant where the valuable nuclear fuel materials (uranium and plutonium) are recovered and purified for reuse. The radioactive fission products are removed as wastes.

Fuel reprocessing generally involves acid dissolving of the fuel material from the undissolved cladding, followed by two or three cycles of purification of the uranium and plutonium by solvent extraction. The uranium is then calcined to $\mathrm{UO}_{3}$ or converted to $\mathrm{UF}_{6}$, and the plutonium is concentrated as an aqueous nitrate solution or calcined to $\mathrm{PuO}_{2}$ for return to the fuel cycle.

Most of the volatile fission products (noble gases and iodine) are volatilized during the fuel dissolution step. The noble gases (primarily krypton-85) are discharged to the atmosphere. Greater than $99 \%$ of the radioiodine is removed from the dissolution gases by combinations of aqueous scrubbing, adsorption on solids, and filtration. These iodine-containing materials are then stored for decay and/or packaged for burial.

Appruxinatcly $99.9 \%$ or the nonvolatile and intensely radioactive nuclides are removed in the high-level aqueous waste from the first solvent cxtraction. The high level wastes are composed of aqueous nitrate solutions (and sometimes sulfates are present) of metallic constituents (chemicals added during reprocessing plus the fission products). These wastes are stored under carefully controlled conditions to prevent them from entering our environment. Currently, these a. Activation products are materials which were transformed from nonradioactive to radioactive nuclides by the absorption of surrounding nuclear particles. 
wastes are concentrated to minimum volumes and stored in large underground tanks, as either as-received acid or as alkaline salt solutions. A recently imposed regulation requires that in the future these high-level wastes must be converted to an encapsulated, disposable, solid form within five years after reprocessing, and the solids must be shipped to a federal repository within ten years after reprocessing for final disposal. (9)

A small amount of radionuclides is discharged to the rivers. These wastes originate primarily from process condensates, laundry wastes, some decontamination operations, and floor drains. Treatment of these materials consists primarily of distillation, ion exchange, and precipitationflocculation.

A relatively large volume of miscellaneous solid wastes which contain significant amounts of radionuclides are packaged and buried. These wastes consist of general contaminated trash, filed equipment, used ventilation filters, paper and rag decontaminating materials, and the chopped-up fuel cladding hulls. Large-sized equipment is packaged in specially-built large containers. Most other material is packaged in steel drums, but some is placed in paper or wood cartons. Concrete is used for shielding as necessary. Currently, these wastes are being buried in trenches on-site. However, Reference (9) requires that solid wastes which contain measurable amounts of plutonfun (dind must of thesc waste-materials qualify) must also be buried in a federal repository in the near future.

The estimated radionuclide emissions for 1970 from fuel reprocessing are summarized in Table 7. The significant "discharges" are those which are stored, except for tritium and krypton, and the latter isotopes have high allowable values for emissions. Only a few of the values in Table 7 are reported values, $(10)$ with the remaining obtained from References (11) and (12) and from the authors' interpretations. The key point is that all discharges are a small fraction of acceptable levels.

Extrapolation to discharges in the future from the values in Table 7 must be done with extreme caution because: (1) total fuel processed in 1970 (approximately 50 MT) was a very small amount, average burnup in the fuels processed was generally luw, arid average age of the spent fuels was relatively old; and (2) process schemes for future reprocessors may very well be sufficiently different to cause significant shifts in the discharges of radionuclides, particularly krypton and tritium.

SOLIDIFICATION AND DISPOSAL

As stated previously, the only currently practicable method for disposing of nuclear wastes which have greater than acceptable amounts of radionuclides is to store these wastes for centuries under carefully controlled conditions. During this aging and decaying period for the radionuclides, the wastes must be kept out of man's biosphere. The most important wastes are the high-level wastes obtained during reprocessing of the spent nuclear fuel, and wastes which contain significant amounts of plutonium (primarily, those from fuel fabrication operations). Obviously, the control of these wastes to prevent them from entering man's environment for the very long time periods is a formidable task.

Storage of wastes as liquids in nearsurface tanks has been a successful means for containing the radioactive wastes to date. Such storage is considered to be temporary only, because the waste is contained in a mobile form within our biosphere, the tanks must be periodically replaced due to failure by corrosion, and continual operation and surveillance are required.

Other disposal alternatives which have been investigated in the research and development programs sponsored by the U.S. Atomic Energy Commission are: (1) disposal as solids in surface or near-surface valults: $(13)$ (2) disposal as liquids or slurries in caverns in deep geologic formations; $(14)$ and (3) disposal as solids in caverns in deep geologic formations. (15)

Disposal of wastes as solids in surface or near-surface vaults on commercial reprocessing plant sites appears acceptable for interim storage. However, for the very long term, surface disposal of solids is considered to be less favorable than disposal in selected deep geologic formations because of the requirement of continued surveillance.

\section{Disposal in Salt}

Disposal of high-level waste as solids in selected deep geologic formations appears acceptable from both the safety and economic standpoints. The initial stimulus for this part of the AEC effluent control R\&D program commenced in September 1955, when, at the request of the Atomic Energy Commission, a committee of geologists and geophysicists was established by the National Academy of Sciences-National Research Council to study the possibilities of disposing of high-level radioactive waste materials on land, and to 
indicate what research was needed to determine the feasibility. (16)

The results of this Committee's study and their recommendations can be summarized as follows:

"Disposal in salt is the most promising method for the near future. Research should be pushed immediately on the structural problem of stability vs size of cavities at a given depth; on the thermal problem - getting rid of the heat or keeping it down to acceptable levels...."

Salt formations are attractive for waste disposal because: (1) salt formations are widespread and abundant, underlying about 500,000 square miles in portions of 24 states; (2) salt has good structural properties, with a compressive strength and radiation-shielding characteristic similar to concrete; (3) salt 1s relatively inexpensive to mine; (4) salt has better thermal conductivity and heat capacity than most other rock types; and bedded salt formations are isolated from underground aquifers by essentially impermeable shale. Fractures that might develop are healed by plastic deformation and recrystallization of the salt.(17) Salt formations which are desirable for disposal of radioactive wastes should be at least 200 feet thick, and should be within 2000 feet of the surface.

In this waste disposal concept, solid, encapsulated waste is transported to a previously excavated salt mine and placed above shafts that extend down into the mine.

For the low-level, plutonium-containing wastes, the previously-packaged wastes will be handled directly. At mine level, the wastes will be picked up by fork lifts and transported to the disposal rooms where they will be unloaded and stacked. When a room is filled with waste, it will be backfilled with crushed salt and sealed with masonry stoppings.

The high-level waste is transferred through its shaft to a shielded, manuallyoperated carrier in the mine. The waste is then transferred to a room in the mine and placed in pre-excavated vertical holes in the floor. Crushed salt is put into the hole to fill the annulus between the waste can and the wall of the hole and to fill the 6 to 8 feet of hole above the waste can for shielding. The process is continued until all the holes in a room are filled. Excess salt chips from the mining operation are then used to backfill the room.
For each type of waste, the salt will eventually plastic-flow under the pressure of the overburden to compress the crushed salt in the room to a monolithic formation, thus sealing the waste in salt.

A plan view of a concept for high-level waste is shown in Figure 3 as developed by ORNL workers. The connecting peripheral tunnels are used for ventilation control.

Present plans call for the alpha (lowlevel) repository to be completed in December 1964, and the high-level repository to be completed in January 1976. (17) When in operation, the U.S. Government will be responsible for operating the mines through an operating contractor. Customers will be charged a one-time fee for disposing of each package of their waste.

Maximum container sizes for the luwlevel wastes are expected to be 1 imited to 4 by 6 by 6 feet and should weigh no more than 5 tons. For high-level waste, the maximum container size is 2 feet in diameter by 10 feet long, and should weigh no more than 2 tons.

\section{Conversion of High-Level Wastes to Solids}

The conversion of high-level wastes to solids as a pretreatment for final storage is being developed in nearly all countries with significant near-future nuclear energy. Solidification is being developed so widely because it is the only reasonably attainable technique for achieving a substantial increase in the safety associated with the storing ald dispusdl of the high-level waste from the nuclear power industry.

Storage and transportation of high-level wastes as solids will provide significantly more safety than liquids because solid wastes are:

- Immobile

- Less soluble in water

- Considerably smaller in voilume, and

- More rugged physically than those stored as liquids.

As a result of research and development conducted in the past 16 years, four processes for solidification of high-level wastes have been developed in the USA to the point of radioactive demonstrations on an engineering-scale. The processes are pot calcination, spray solidification, phosphate glass solidification, and fluidized bed calcination. 
In all four processes, heat is applied to raise the temperature of the waste to 400 to $1200^{\circ} \mathrm{C}$. At these temperatures, essentially all of the volatile constituents (primarily water and nitrates) are driven off, leaving a calcined solid or a melt that will cool to a monolithic solid.

The simplest chemistry for solidification is in processes that form calcines. Calcines consist of mixtures of the nonvolatile oxides (and sometimes sulfates or fluorides, if present) of the metallic salt constituents in the wastes. All other materials are volatilized. For calcines, the minimum weight of solidified high level waste (that from fission product oxides alone) is about $1.1 \mathrm{~kg} / 1000$ $\operatorname{MWd}(t)$ exposure. Contributions from nonradioactive chemicals added during fuel reprocessing can increase that weight by factors up to 4 .

Solidification processes which form melts require significant chemical modification of the chemical composition of the waste. Generally, at least 70 mole \% of inert chemicals are required to incorporate the fission products into materials that are mel table at reasonably low temperatures, or less than about $1000^{\circ} \mathrm{C}$. Melts have been developed in which the major mel tmaking fluxes are phosphates $(18,19,20)$ silicates, $(21,22)$ or borates, $(23)$ or some combination of these. $(24,25,26)$ In most cases, potentially workable chemical composition ranges have been defined. (27)

With the disposal of high level wastes in salt mines, a very important time period for control of radionuclides is during the first 10 years after solidification when the heat removal problems, temperature, radioactivity, and rate of temperature change are the greatest, and during transportation to the long-teril disposal site.

To provide this increased safety, the desired characteristics of solidified wastes with primary importance are:

- Good thermal conductivity,

- Low leachability,

- Good chemical stability and radiation resistance,

- Mechanical ruggedness,

- Noncorrosiveness to container,

- Minimum volume,

- Minimum cost.

Typical characteristics of solidified high level wastes from reprocessing are shown in Table 8.

The solidified waste from pot calcina- metallic constituents in the original liquid waste. The solid is a porous, friable calcine with a low thermal conductivity and a relatively high solubility in aqueous solutions.

The spray solidified waste is a monolithic solid formed after cooling the melt. The solid is a tough, microcrystalline, rocklike material with good thermal conductivity and a moderately low solubility.

The phosphate glass solid is a monolithic, moderately brittle glass formed after cooling the melt. The glass has a fairly good thermal conductivity and a low solubility in aqueous solutions.

The fluidized bed calcine is granular with a mean particle diameter of about 500 microns. The granules may be composed of crystals or amorphous solids. The granules are generally spherical in shape and are moderately soft and friable. Their thermal conductivity is relatively low.

A photograph of the four types of solidified wastes is presented in Figure 4.

A number of cost estimate studies have been made by Blomeke and coworkers at ORNL for high-level waste management. These studies have investigated the total costs of managing high-level wastes, which include interim liquid storage, conversion to solids by pot calcination, interim solids storage at the fuel reprocessing plant, transportation of solids to a salt mine, and handling and burial of the solid waste in a salt mine. For the cases examined, costs for total waste management are estimated to be in the range of 37 to $45 \mathrm{milis} / \mathrm{MW} \mathrm{hr}$, or $\$ 9500$ to $\$ 12,000$ per metric ton of fuel processed. These costs represent approximately $1 \%$ of the total cost of nuclear power.

\section{SUMMARY}

The total amounts of radioactive materials in the wastes from the mainline activities of fast-growing nuclear power generation in the USA in 1970 have been estimated and presented. In essentially all cases, the performance of industry in minimizing waste emissions to our environment has been very good, with most emission points evolving radioactivity less than a few percent of conservative, acceptable limits. Where very large amounts of radionuclides are present in wastes, in particular during reprocessing of spent nuclear fuel, the wastes are stored. Final disposal of stored high level and plutonium-containing wastes is 
planned to involve conversion to solids and burial in a federally-owned salt mine repository in the mid-seventies. In this repository, the salt is expected to seal the wastes from our biosphere for the geologic time period required.

\section{REFERENCES}

1. Mckee, R.W.: Chapter 8, "Promethium from Power Reactors," Promethium Technology, edited by E.J. Wheelwright, publication in progress 1971.

2. Code of Federal Regulations, Title 10, Part 20, January 1, 1970.

3. Statement of the Committee on Mining and Milling, Atomic Industrial Forum, Inc., in Hearings Before the Subcommittee on Research Development and Radiation of the Joint Committee on Atomic Energy, June 7, 1967.

4. Personal communtcation. K. J. Schneider and R.D. Dierks, Battelle-Northwest, March 1971. Unpublished data from task force study on waste discharges from the nuclear fuel cycle.

5. Personal communication. K.J. Schneider and J.R. Young, Battelle-Northwest, March 1971. Unpublished data from task force study on waste discharges from the nuclear fuel cycle.

6. Personal communication. K.J. Schneider and J.B. Burnham, Battelle-Northwest, April 1971. Unpublished data from task force study on waste discharges from the nuclear fuel cycle

7. Van Tuyl, H.H., Winegardner, W.K., Hilliard, R.K., and Cooley, C.R.: A Survey of the Alpha Waste Generation and Disposal as Solids in the US Nuclear Fuel Industry, Battelle-Northwest, Rich land, Washington, BNWL-B-34. (December 1970)

8. Personal conmunication. K.J. Schneider and E.T. Merril1, Battelle-Northwest, April 1971. Unpublished data from task force study on waste discharges from the nuclear fuel cycle.

9. US Federal Register, Appendix F to 10CFR50, Policy Relating to the Siting of Commercial Fuel Reprocessing Plants and Related Waste Management Facilities, November 14, 1970.

10. "Statements of Staff of Nuclear Fuel Services Company", Atomic Energy Weekly News letter, Vol. 16, N0. 29, July 20, 1970.

11. Fersonál Cünmunication. K.j. Jchneider and L.K. Mudge, BNW, April 1971. Unpublished data from task force study on was te discharges from the nuclear fuel cycle.

12. Siting of Fuel Reprocessing Plants and Waste Management Facilities, ORNL-4451, July 1970.

13. Perona, J.J., et.al.: Comparative Costs for Final Disposal of Radioactive Solids in Concrete Vaults, Granite, and Salt Formations, USAEC Rep. ORNL-TM-664 (1963).

14. Belter, W.G.: Ground Disposal of Radioactive Waste in an Expanding Nuclear Power Industry Annual Meeting of American Institute of Mining, Metallurgical, and Petroleum Engineers, Washington, D.C. (1969).
15. Regan, W.H., Ed:Proceedings of the Symposium on the Solidification and Long-Term Storage of Highly Radioactive Was tes, USAEC Rep. CONF-660208, Richland, Washington (1966).

16. Committee on Waste Disposal of the Division. of Earth Sciences, Disposal of Radioactive Wastes on Land (National Academy of SciencesNational Research Council Publication 519) (1957).

17. Blomeke, J.0. and McClain, W.C.: "A Salt Mine Repository for Radioactive Waste", Nuclear News, Vol. 14, No. 4 (April 1971).

18. Mendel, J.E., Rey, G., McElroy, J.L.: "Design Verification Testing of Waste Solidification Processes", USAEC Rep. CONF-660208 (Richland, Washington Symposium 1966).

19. Barton, G.B.: Solidification of High-Level Wastes, Part IV, Phosphate Melts for Fixation of Radioactive Residues from Purex Type Wastes, Three to Fifty Percent Fission Product 0xides, USAEC Rep. BNWL-80 (1965).

20. Barton, G.B.: Solidification of High...Level Wastes, Part V, Factorial Study of the Effect of Varying the Concentration of the Components of Purex Type Waste on the Properties of Phosphate Solids, USAEC Rep. BNWL-544 (1968).

21. Johnson, K.B., Grover, J.R., Hardwick, W.H.: Work in the United Kingdom on fixation of highly radioactive wastes in glass, A/CONF. 28 (Geneva Symposium 1964) 188.

22. Bonniaud, R.: "Survey of the Studies Conducted in France on the Solidification of Concentrated Fission Products", USAEC Rep. CONF-660208 (Richland Washington Symposium 1966).

23. Kaser, J.D., Moore, J.D.: "The Development of a Spray-Calciner-Melter", USAEC Rep. CONF-660208 (Richland, Washington Symposium 1966).

24. Barton, G.B.: Solidification of High Level Wastes, Part VI, Mixed Phosphate, Borate, Silicate Melts for Fixation of Purex Type. Wastes, USAEC Rep. BNWL-373 (1967).

25. Mende 1, J.E.: "Preparation of Melts from Solidified Waste", Quarterly Progress Report, Research and Development Activities, Fixation of Radioactive Residues (Platt, A.M. Ed.) USAEC Rep. BNWL-76 (1965).

26. Clark, W.E., Godbee, H.W.: "Fixation of Simulated Highly Radioactive Wastes in Glassy Sollds", (Vienna Symposium 1962).

27. Schneider, K.J., Ed.: Waste Solidification Program, Volume 1, Technology for the Pot, Spray, and Phosphate Glass Solidification Processes, USAEC Rep. BNWL-1073 (1969).

\section{ACKNOWLEDGMENTS}

This paper is based on work performed for the United States Atomic Energy Commission. 
TABLE 1 - IMPORTANT RADIONUCLIDES IN WASTES FROM THE NUCLEAR POWER INDUSTRY

\begin{tabular}{|c|c|c|c|c|c|}
\hline & $\begin{array}{l}\text { Usual } \\
\text { Form } \\
\end{array}$ & $\begin{array}{l}\text { Half- } \\
\text { Life }\end{array}$ & $\begin{array}{l}\text { Maximum Permiss } \\
\text { Concentration, } \\
\text { Air }\end{array}$ & $\begin{array}{l}\text { ible } \\
\mu \mathrm{Ci} / \mathrm{cc} \\
\text { Water }\end{array}$ & $\begin{array}{l}\text { Source } \\
\text { of Main } \\
\text { Concern } \\
\end{array}$ \\
\hline Sodium-24 & $\mathrm{L}$ & $15 \mathrm{~h}$ & $1 \times 10^{-6}$ & $6 \times 10^{-3}$ & $\mathbf{R}$ \\
\hline Radon-222 & G & $3.8 \mathrm{~d}$ & $1 \times 10^{-7}$ & -- & M \\
\hline Xenon-133 & G & 5.3. d & $1 \times 10^{-5}$ & -- & $\mathbf{R}$ \\
\hline Iodine-131 & G & $8 \mathrm{~d}$ & $9 \times 10^{-9}$ & $6 \times 10^{-5}$ & $\mathrm{R}, \operatorname{Rep}$ \\
\hline Phosphorous-32 & $\mathrm{L}$ & $14.3 \mathrm{~d}$ & $7 \times 10^{-8}$ & $5 \times 10^{-4}$ & $R$ \\
\hline Curium-242 & $\mathrm{L}, \mathrm{S}$ & $163 \mathrm{~d}$ & $1 \times 10^{-10}$ & $7 \times 10^{-4}$ & Rep \\
\hline Cerium-144 & $\mathrm{L}, \mathrm{S}$ & $240 \mathrm{~d}$ & $6 \times 10^{-9}$ & $3 \times 10^{-4}$ & Rep \\
\hline Ruthenium-106 & $G, L, S$ & $1 \mathrm{y}$ & $6 \times 10^{-9}$ & $3 \times 10^{-4}$ & Rep \\
\hline Krypton-85 & G & $10.7 \mathrm{y}$ & $1 \times 10^{-5}$ & -- & $\mathrm{R}, \operatorname{Rep}$ \\
\hline Hydrogen-3 & $G, L$ & $12.3 \mathrm{y}$ & $5 \times 10^{-6}$ & $1 \times 10^{-1}$ & $R, \operatorname{Rep}$ \\
\hline Strontium-90 & $\mathrm{L}, \mathrm{S}$ & $28.9 \mathrm{y}$ & $1 \times 10^{-9}$ & $1 \times 10^{-5}$ & $R$, Rep \\
\hline Cesium-137 & $\mathrm{L}$ & $30.2 \mathrm{y}$ & $6 \times 10^{-8}$ & $4 \times 10^{-4}$ & $\mathrm{R}, \mathrm{Rep}$ \\
\hline Americium-241 & $\mathrm{L}, \mathrm{S}$ & $433 \mathrm{y}$ & $6 \times 10^{-12}$ & $1 \times 10^{-4}$ & Rep \\
\hline Radium-226 & $\mathrm{s}$ & $1600 y$ & $3 \times 10^{-11}$ & $4 \times 10^{-7}$ & $M, P \& E$ \\
\hline Plutonium-239 & $\mathrm{L}, \mathrm{S}$ & $24,000 \mathrm{y}$ & $2 \times 10^{-12}$ & $1 \times 10^{-4}$ & $F, \operatorname{Rep}$ \\
\hline Uranium-238 & $\mathrm{L}, \mathrm{S}<4$ & $4,500,000,000 \mathrm{y}$ & $1 \times 10^{-10}$ & $1 \times 10^{-3}$ & All \\
\hline
\end{tabular}

\begin{tabular}{ll}
\hline M Mining and Milling \\
P\&E & Purification and Enrichment \\
F & Fuel Fabrication \\
R & Reactor \\
Rcp & Rcprocessing
\end{tabular}

*MPC's are for occupational exposure in accordance with reference (2).

TABLE 2 - CLASSIFICATION OF RADIOACTIVE WASTES

\begin{tabular}{|c|c|c|c|c|c|}
\hline $\begin{array}{l}\text { Nominal } \\
\text { Lèvè1 }\end{array}$ & $\begin{array}{l}\text { Times } \\
\text { MPC }\end{array}$ & $\frac{\text { Concentra }}{\text { Air }}$ & $\frac{1, \mu \mathrm{Ci} / \mathrm{cm}^{3}}{\text { Water }}$ & $\begin{array}{c}\text { Shielding } \\
\text { Requirements }\end{array}$ & Remarks \\
\hline Low & $1 / 30$ & $<1 \times 10^{-11}$ & $<\overline{1 \times 10^{-7}}$ & None & $\begin{array}{l}\text { For population at } \\
\text { large }\end{array}$ \\
\hline Low & 1 & $<1 \times 10^{-9}$ & $=1 \times 10^{-5}$ & None & Or.rupational \\
\hline Intermediate & $<10^{4}$ & $<1 \times 10^{-5}$ & $<1 \times 10^{-1}$ & Light & $\begin{array}{l}\text { Treated (or } \\
\text { diluted) }\end{array}$ \\
\hline High-Inter & $<10^{8}$ & $<0.1$ & $<1 \times 10^{3}$ & Heavy & Requires treatment \\
\hline High & $>10^{8}$ & $>0.1$ & $>1 \times 10^{3}$ & Very Heavy & $\begin{array}{l}\text { Requires treatment; } \\
\text { self-heating }\end{array}$ \\
\hline
\end{tabular}


TABIE 3 - ESTIMATED RADIONUSLIDES IN

WASTES FROM URFNIUM MILLING IN $=973$

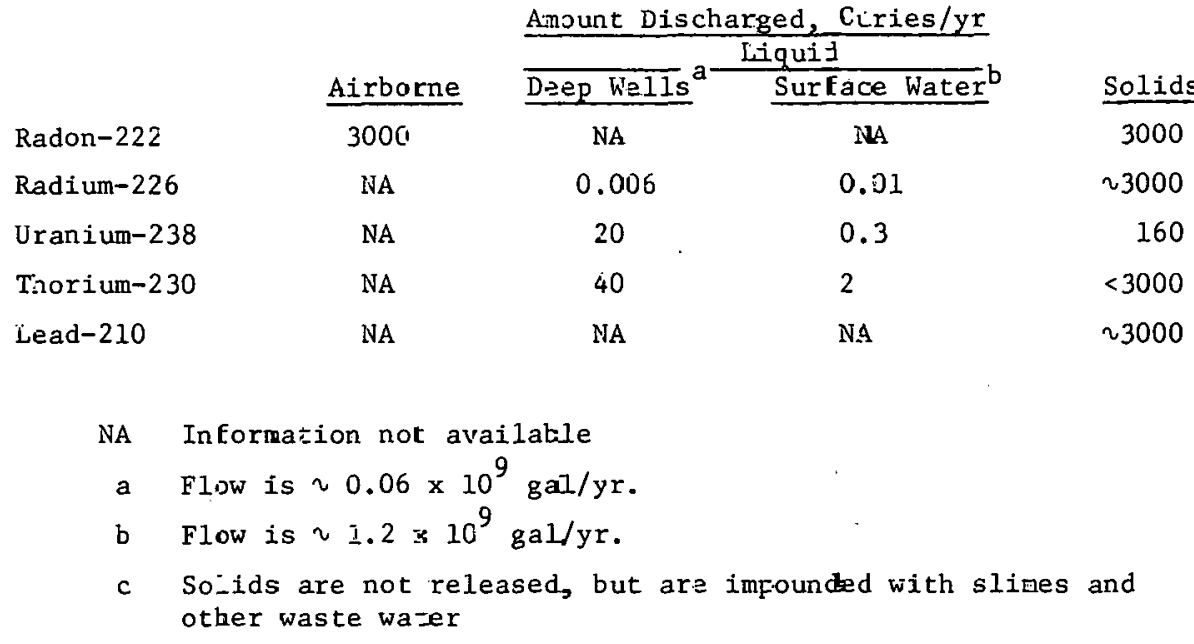

TAELE 5A - ESTTMATED URANTUM IN KASTES FROM FUEL ELEMENT FA3RIIATION IN 1970

Amount Discharced, Curies/yr

\begin{tabular}{|c|c|c|c|c|}
\hline & $\mathrm{Gas}^{\mathrm{b}}$ & $\begin{array}{l}\text { Liquids: } \\
\text { to Rivers }\end{array}$ & $\begin{array}{l}\text { Solids } \\
\text { to Barial d } \\
\end{array}$ & \\
\hline $\mathrm{U}-234^{\mathrm{a}}$ & 14 & 30 & 0.002 & $\mathrm{Pu}-238$ \\
\hline U-235 & $0 . \overline{0}$ & 1 & C. .00009 & $\mathrm{Pu}-239$ \\
\hline \multirow[t]{2}{*}{$\mathrm{U}-238$} & 3 & 8 & C. .0005 & $\mathrm{Pu}-240$ \\
\hline & & & & $\mathrm{Pu}-241$ \\
\hline
\end{tabular}

TA3LE 4 - ESTIMATED RADIONCCLIDES IN WASTES FROM PURIFICATION AND CONVERSION TO UF 6 IN 1970

Anount Discharged, Curies/yr

\begin{tabular}{|c|c|c|c|}
\hline \multirow[b]{2}{*}{ Gas } & \multicolumn{2}{|c|}{ Liquid } & \multirow[b]{2}{*}{ Solids ${ }^{c}$} \\
\hline & to Ponds ${ }^{a}$ & to Rivers ${ }^{b}$ & \\
\hline NA & 1 & 1 & NA \\
\hline NA & 0.2 & NA & 56 \\
\hline NA & 4 & NA & 1600 \\
\hline NA & NA & NA & NA \\
\hline
\end{tabular}

NA Infozmation not available

a. Flow is $L$ to 10 million gallons/yr.

b. Flow is approsinately 40 million gallons/yr.

c. Total vo-ume is unknown.

TABIE 5B - EOTCMATED PLUTONIUM IN WASTES FROM FUEL E-E:IEET IABRICATION $-\mathrm{N} 1.970$

\begin{tabular}{|c|c|c|}
\hline $\mathrm{Gas}^{\mathrm{a}}$ & $\begin{array}{l}\text { Liquids } \\
\text { to Rivers a }\end{array}$ & $\begin{array}{l}\text { Solids } \\
\text { to Burial }\end{array}$ \\
\hline NA & NA & 1,000 \\
\hline NA & $\mathrm{NA}$ & 200 \\
\hline NA & NA & 270 \\
\hline $\mathrm{NA}$ & NA & 70,000 \\
\hline
\end{tabular}

a. The amount of U-234 present is increased froc the previous enrichment step.

b. Total uranium is apgroximately $10,000 \mathrm{~kg}$.'yr.

c. Total uranium is apfroximately $25,000 \mathrm{~kg}$. $y r$.

d. Volume is approximately $300,000 \mathrm{zt} / \mathrm{yr}$. Total uranium is ap roximately $2 \mathrm{~kg} / \mathrm{yr}$.

a. Values are unknowr. tout are very low.

b. Total pluçon-um is $6 . \mathrm{kg}$. Total volure is approximately $25,000 \mathrm{ft} / \mathrm{yr}$. 
TABLE 6 - ESTIMATED RADIONUCLIDES IN WASTES FROM NUCLEAR REACTORS IN 1970

Amount Di.scharged, Thousands of Curies/yr

$$
\begin{aligned}
& \mathrm{N}-13, \mathrm{~A}-41 \\
& \mathrm{Kr}-85,-85 \mathrm{~m},-87,-88^{\mathrm{a}} \\
& \mathrm{I}-129,-131,-132,-133,-13 \\
& \mathrm{Xe}-131,-133 \mathrm{~m},-133,-135 \mathrm{~m}, \\
& \quad-135,-138 \mathrm{a} \\
& \mathrm{H}-3 \\
& \mathrm{Nm}-54 \\
& \mathrm{Fe} \\
& \mathrm{Co}-58,-60 \\
& \mathrm{Ni}-63 \\
& \mathrm{Sr}-90 \\
& \mathrm{Mo}-99 \\
& \mathrm{Ng}-108,-110 \\
& \mathrm{Cs}-134,-137
\end{aligned}
$$$$
\text { I-129, }-131,-132,-133,-135
$$$$
-135,-138 \text { a }
$$

Gas Liquids ${ }^{b} \quad \begin{aligned} & \text { Solids to Burial } \\ & \text { to Rivers }\end{aligned}$

6
1,300
-
2,000

6

$-$

(1)

20

$-$

$-$

$-\quad 0.001$

- $\quad-$

- $\quad-$

$-\quad 0.04$

$-$
- $0.02 \quad 200 \quad-$

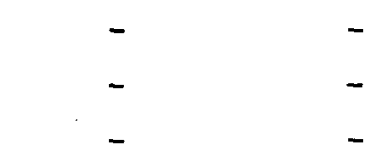

$0.06 \quad 1$

0.032

$0.9 \quad 50-60$

$0.6 \quad 0.2$

$0.1 \quad 1$

$0.02-$

$\begin{array}{lll}0.04 & - & - \\ - & - & 40\end{array}$

a. Creater than $99 \%$ of the radionuclides of krypton and xenon have half-lives of 12 days or less. Approximately $0.01 \%$ is 10.7 years krypton-85.

b. Total volume for a $1,000 \mathrm{MWe}$ reactor varies from 200,000 to about $6,000,000 \mathrm{gal} / \mathrm{yr}$.

c. Total volume for a 1,000 MWe reactor is 5,000 to $10,000 \mathrm{ft}^{3} / \mathrm{yr}$.

d. Includes control rods. Total volume for a 1,000 MWe reactor is approximately $10 \mathrm{ft}^{3} / \mathrm{yr}$. 
TABLE 7 - ESTIMATED RADIONUCLIDES IN WASTES FROM NUCLEAR FUEL REPROCESSING IN 1970

Amount Discharged and Stored, Thousands of Curies/yr

\begin{tabular}{|c|c|c|c|c|}
\hline \multirow{2}{*}{ 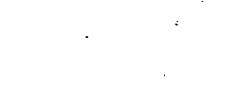 } & \multirow{2}{*}{$\mathrm{Gas}^{\mathrm{a}}$} & \multicolumn{2}{|c|}{ Liquids } & \multirow{2}{*}{$\begin{array}{l}\text { Solids } \\
\text { Buried }\end{array}$} \\
\hline & & to Rivers ${ }^{b}$ & Storcd ${ }^{c}$ & \\
\hline $\mathrm{H}-3$ & 2 & $b$ & - & - \\
\hline$K_{1}=83$ & $30 n$ & - & - & - \\
\hline $\mathrm{Sr}-90$ & 0.0005 & 0.01 & 2,000 & $0.1 .2^{\circ}$ \\
\hline $2 x-N b-95$ & 0.0007 & 0.001 & 5,000 & $250^{f}$ \\
\hline Ru-106 & 0.0002 & 0.01 & 11,000 & - \\
\hline$I-131^{g}$ & 0.00003 & - & - & - \\
\hline Cs -137 & 0.00004 & 0.01 & 3,000 & $0.03^{e}$ \\
\hline $\mathrm{Ce}-144$ & 0.0002 & 0.001 & 20,000 & $2^{e}$ \\
\hline $\mathrm{Pu}$ isotopes & - & - & 8 & $6^{h}$ \\
\hline $\mathrm{cm}-242$ & - & - & 300 & $0.7^{\mathrm{h}}$ \\
\hline U-isotopes & - & - & 0.00003 & 0.00002 \\
\hline
\end{tabular}

a. For a typical 1 to $5 \mathrm{MT} /$ day $\mathrm{plant}$, these radionuclides are mixed with 50,000 to $100,000 \mathrm{cfm}$ of ventilation air.

b. The volume of these wastes is in the nrder of 10,000 yullons/M'l fuel.

c. The volume of these wastes is typically in the order of 50 to 200 galluus/MT fuel.

d. The volume of these wastes is typically in the order of $200 \mathrm{ft}^{3} / \mathrm{MT}$.

e. Taken at 0.01 percent of total in spent fuel.

$f$. The number includes large amounts of Co-60 and Fe-55.

8. The values are negligible for 1970 because all fuel processed was at least one year cooled. For more typical 150-day cooling, the values would be in the order of 0.001 thousands of curies (approximately $1 \mathrm{Ci}$ ) in each of the four waste streams.

h. Assumed at 0.23 percent of the total in the spent fuel. 
TABLE 8 - CHARACTERISTICS OF SOLIDIFIED HIGH- LEVEL PUREX WASTES

\begin{tabular}{|c|c|c|c|c|}
\hline & Pot Calcine & Spray Melt & $\begin{array}{l}\text { Phosphate } \\
\text { Glass }\end{array}$ & Fluid Bed \\
\hline Form & Calcine cake & Monolithic & Monolithic & Granular \\
\hline Description & Scale & Microcrystalline & Glass & Amorphous \\
\hline Mole \% Fission Product Oxides & Up to 80 & Up to 20 & Up to 25 & Up to 50 \\
\hline Bulk Density, $\mathrm{g} / \mathrm{ml}$ & 1.1 to 1.5 & 2.7 to 3.3 & 2.7 to 3.0 & 1.0 to 1.7 \\
\hline Thermal Conductivity, Btu/ (hr) $(\mathrm{ft})\left({ }^{\circ} \mathrm{z}\right)$ & 0.15 to 0.25 & 0.5 to 1.0 & 0.4 to 0.8 & 0.10 to 0.25 \\
\hline Maximum Heat, W/1iter solid ${ }^{(a)}$ & 85 & 205 & 190 & 70 \\
\hline Leachability in Cold Water, $\mathrm{g} / \mathrm{cm}^{2}$-day & 1.0 to $10^{-1}$ & $10^{-3}$ to $10^{-6}$ & $10^{-4}$ to $10^{-7}$ & 1.0 to $10^{-1}$ \\
\hline Hardness & Soft & Hard & Very Hard & Moderate \\
\hline Friability & Crumb1y & Tough & Brittle & Moderate \\
\hline Residual Nitrate, wt\% & $\leq 0.05$ & $\leq 0.005$ & $\leq 0.0005$ & $\leq 4.0$ \\
\hline Volume, 1iters/1000 $\mathrm{MWd}_{\text {th }}$ & 1 to 2.5 & 1.2 to 3 & 1.5 to 5 & 1.5 to 5 \\
\hline Maximum Stable Temperature, ${ }^{\circ} \mathrm{C}$ & $\sim 900$ & $\begin{array}{l}\text { Phase Separation } \\
\text { at } \sim 900\end{array}$ & $\begin{array}{l}\text { Devitrifies } \\
\text { at } \sim 500\end{array}$ & $\sim 600$ \\
\hline Container Material & SS & MS or SS & MS or SS & MS or SS \\
\hline
\end{tabular}

(a) Approximate values for storage in air at 8-inch diameter cylindrical pots to maintain pot centerline temperatures less than $900^{\circ} \mathrm{C}$ and pot wall temperatures less than $425^{\circ} \mathrm{C}$. Average $\mathrm{k}$ values were used. 


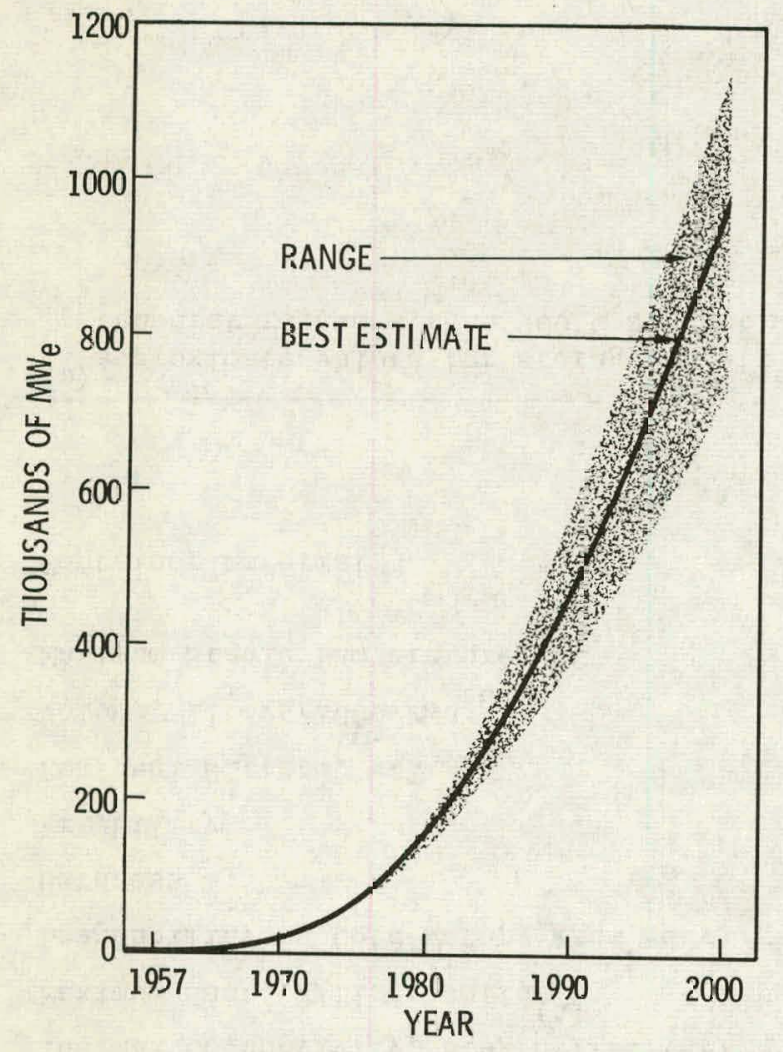

Fig. 1 - Grovth of nacleer power in U.S A,

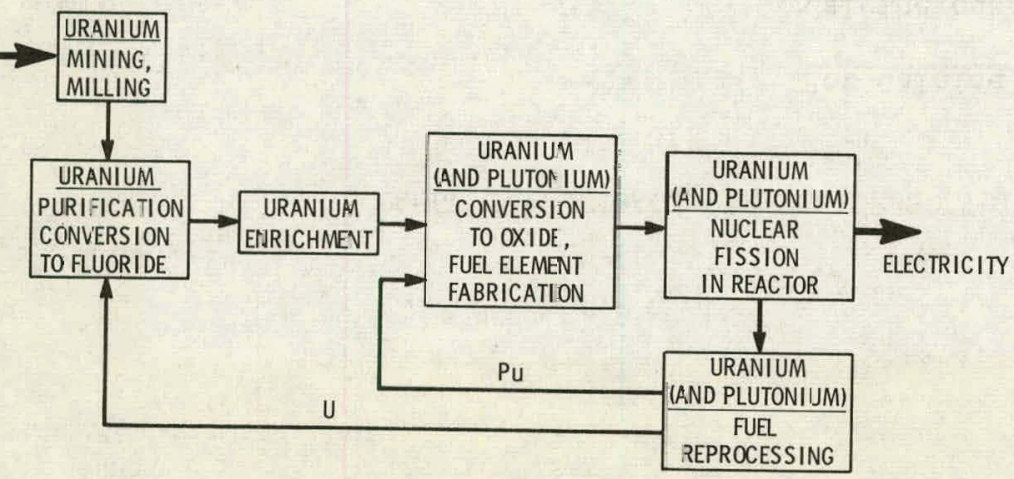

Fig. 2 - Nuclear suel cycle

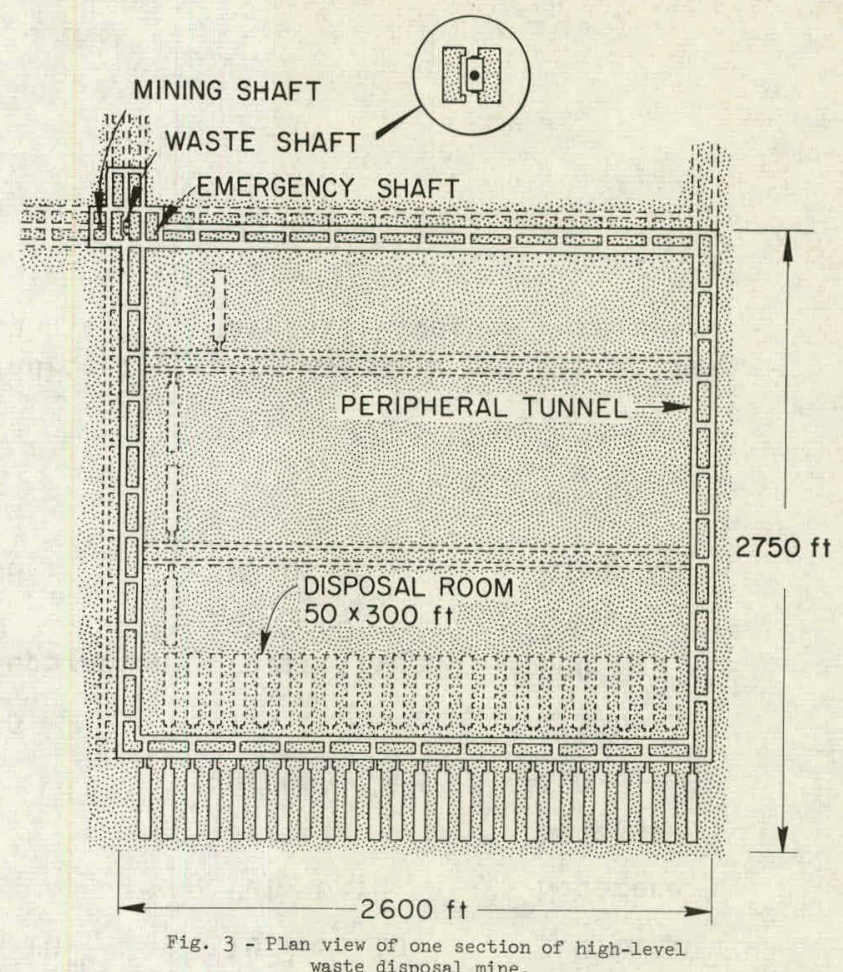

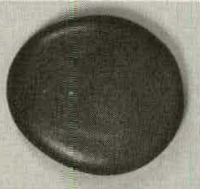

Spray So idification

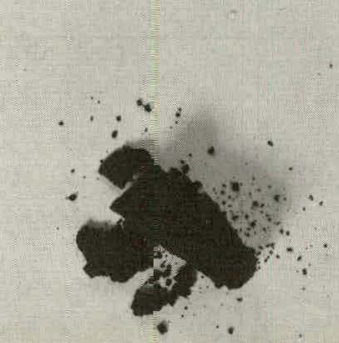

Pot Calcination

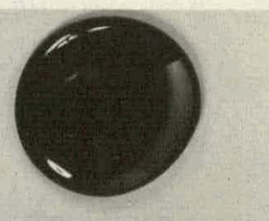

Phosphate Glass

Fluidized Bed Calcination 